\title{
PUBLIC PARTICIPATION IN DEVELOPMENT PLANNING AND MANAGEMENT
}

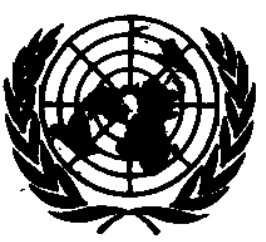

UNITED NATHONS

BCONOMC COMMISSTON POR AFRICA 
BCA/PHSD/PAM/90/4(1.2)(1)(d)

Ualted Natloas

Economic Comelseion for Africa

Public Administration, Human Resources and Soctal Development Division

PUBLIC PARTICIPATION IN DEVELOPABAT PLAMILIG

AND MANAGEMENT

Hay 1990 
A. Public Participation as a Concept 2

3. Concept of Lievelopment Planning 4

C. Concept of Development Management 5

SECTION I: AN OVERVIEY OF COUNTRY EXPERIENCES 10

A. The Issues in Perspective 8

B. Changing Perceptions and the Peorientation 15

c. Impact of Public Participation on the Development Process

SECTION II: THE ROLE OF PUBLIC PARTICIPATION IN THE CHALLETGES OF ECONOMIC RECOVERY

SECXIOH III, STRATEGIES AND MEASURES FOR EFPECTIVE PUBLIC PARTFCIPATION IN DEVELOPITENT PLANNING AHD MANAGEAENT

A. Introduction 25

B. Nacional Strategies and Measures

C. Subregional Strategies and Measures

D. Regional Strategies and Measures

E. Constraints on Sustained Public

Participation

SECTYON IV: COACLUSIONS AND RECOMHENDATIONS FOR POLICY ACTION

IV.2: Suntary Gonclusions 
1. Since independence, successive policies and strategies to improve the social and material well-being of Africa's populations through development planning and management have instead led to excruclating debt burdens and sharp deterioration of living standards across the length and breath of the continent.

2. The gravity of Africa's socio-economic predicament is reflected in, for instance, that less than 30 per cent of the population has access to safe drinking water, 10-30 per cent of the children die before the age of five and the average-1ife expectancy-of adults 1s 51 , between 1982 and 1986,200 million Africans in 24 countries suffered the effects of drought and the threat of famine; educational expendittures fell from $\$ 41$ per caplea in 1980 to $\$ 28$ in 1985 and as many as 40 . per cent of school age children did not attend school in 1984, whilst drop-out rates increased; and to epitomize it all, 26. of the 42 world's least developed countries are in Africa. $1 /$ The Implication of this dysmal scenario is that it would be unrealistic to expect governments to go it all alone in grappling with the daunting challenges of recovery and development.

3. The main purpose of this report is to focus attention on the concept and pragmatism of peoples' contribution to and benefits from the economic and social advancement of African countries and how hest this public participation strategy could be improved and strengthened to speed up the transformation and suctained development of Africa's natural resources and productive forces for the betterment of the quality of human conditions in the region, The specific objectives which flow from this main aim include (a) an at tempt to evolve a common understanding of the terms "Public Participation" and "Development Planning and Management"; $(b)$ overyiew of experiences of public participation in development planning and management in Africa so as to draw lessons to guide future pollcies, strategies and. activities; (c) reflection on the orientation of public

If See for example, The Khartoun Declaration: Towards - HumanFocused Approach to Socio-Economic Recovery and Development in Africa (UNECA, International Conference on the Human Dimemsion of Africa's Economic Recovery and Development, Khartoun, Sudan 5-8 March 1988); UNECA, Economic Report on Africa 1989, Add1s Ababa, April 1989; and Paul Wangoola, "Promoting Indigenous NGOs as Instruments of Popular Participation", A paper prepared for the International Conference on Popular Participation in the Recovery and Development Process in Africa, Arusha, Tanzania, 12-16 February 1990. P.10. 


\section{(5) EA/PHSD /PAM/90/4(1.2)(i)(d) \\ Page 2}

participation, development planning and management in the context of the requirements of the African Alternative Framework to Structural Adjustment Programmes for Socio-economic Recovery and Transformation (AAF-SAP), "the Special Action Programe for Administration : and Management (SAPAM); and for the articulation of: strategies to increase practical and effective public partictpation in Africa's sustained economic and social development management. At the end of the report policy proposals will be suggested for consideration against the demands of future socio-economic development challenges and 'tasks.

\section{A. Public Particlipation as a Concept}

4. Public participation is not a new concept. nhowever whereas it has been articulatel in corporate management and extensively documented in projects" bn "Strategies for Sma11/Farmen:Development"

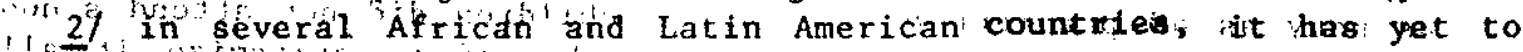
be contextually articulated, documented and operationalized since

- if is centrar to development planning and management il at present as a concept, it its 'subjected to partial analyois land various intérpretations. "In some situations, its understanding by leverybody is erroneously taken for granted. At the outset; it should, therefore, be noted that participation could be public but not necessarily" popular in terms of general acceptability by the population." There is thus a thin but important lire of difference between public and popular participation The thiniline could become thicker if 'popular' is viewed from: the perisective of the I798'french 'Revolution." In the present cotitext; however therlpublic' consists of al indivituals or all the people within ispecific "geographical boundaries which constitute" a nation state, subregion or region. Givent that only the government is better placed to plan and manage the economy in the interest of all the people; it could be taken that public participation connotes partrorship between the people and thesr governiment the interest of national growth and devefopment." Needless to reiterate that the accredited representatives "or leaders of the people constitute the government.

2) See, for example, Elliott R. Morss et'G1, Strategies for Small Farmer Development: An Empirical Study of Rutal Development Projects in The Gantbat, Gfiâna, Kenya, Lesotho; Nigeria, Bolivia, Colombia, Mexico, Paraguay and Peru. Vol:" I: Westriew special stadies in Social, Pólftical and Bconomic Development'(colorado; Westulew Press, Inc. 1976)

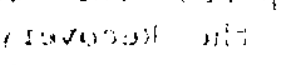

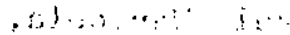

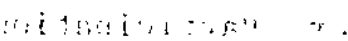$$
\text { eritirsis it }
$$ 
It is thus apparent that public participation is much more than involvement in decision-making. It may be defined as the process whereby."individuals and their government, in a given milieu, share political, social and economic responsibility for and contribute to both the decision-making processes and activities ion national priorities, resource mobilization, allocation and utllization for the advancement of the quality of the soeflal and economie life, of the whole society.

5. Thus, public participation contextually implies that individuals in any. society should not be free or joy-riders who expect everything frop the government, but should be active participants in the develapment process... Fvery person in society is expected not only to share responsibility for the political and socio-economic destiny of the society in which he/she lives and earns his/her living but also to make reasonable contribution to and sacrifices for the planning and management processes and activities which would lead to an improvement in the material wellbeing and quality of life of everyone in the society. The externalfties or spillovers of the self-sustaining activities of individuals will contribute to national development only if harnessed and directed towards the developmental aspirations of the whole nation. In the partnership for national growth and development, the government is better placed to tap and pool the resources and resourcefulness of its people for societal development.

6. In the light of this analytical perspective, public participation further implies that everything which improves the quality of life entails some costs in terms of commitment and utilization of material and financial resources. For instance, payment trust somehow be made for education and medical care which some people would"like to regard as free. In essences. therefore, promites of free soclal services must be placed in their proper and realistic context. Public participation requires that every person in "sociefy must acrifice and make financial and/or other resource contribution to make it possiple for the government to provide social services. This is an aspect of public participation which is usually"given marginal consideration in the government-people alliance for national economic development management.

7. So far, public participation has been considered without reference to the nature and quality of participation except for the reference to the fact that public and popular participation are not necessarily synonymous"expressions. Universal adult suffrage is known as a popular form of public participation in the selection of persons who would form a government or leadership group of any organisation. It is also well-known that adult suffrage became universal in some countries not too long ago and exists only on paper "in some countries with authoritarian and milftary regimes. In terms of nature and quality, therefore, public participation may be spontaneous, subtly or overtly coercive, orchestrated and 
ECA/PHSD/PAM/90/4(1.2)(i)(d)

Page 4

ephemeral or latent and requires stimuli or catalyst to elicit and vitalize it for national development: The nature and quality: of public participation would influence the outcome of development planing and management of the economy.

\section{B. Concept of Development Planning}

8. In the contextual definition of public participation in paragraph 4 of this report, there is also an incidental definition of development planiling. This could be elaborated in view of ithe pragmatic approach which African countries have tended to adopt in development planning since the late 1970s against the background of the sophistication of international economic relations and the failure of past development plans to respond appropriately to contemporary economic challenges:

9. The operationalization of the concept of development has continued to: be tllusive. Over the years, even World Bank (IBRD) efforts $3 /$ to resolve the problem of hiatus between development theory and practice especially in its less developed client nations do not appear to have "paid the expected dividends. "There" is increasing consensus, however, that development is much more than growth. Although the increase in the gross national product (GNP) which reflects the increase in goods and services a country produces still remains the only significant quantitative criterion for the determination of the productive strength of a country's economy, it is generally agreed that the GNP growth is no longer regarded as the main objective or index of development. The latter should mean growth plus change in the quality and standard of living of everyone in the population of a country. Admittedly, growth in the output of goods and services must take place so that a country would have sometiling to distribute to the people. However, development should be viewed as the process whereby the real per capita income of a country increases over a long period af $t$ ime, subject to the proviso that the number of people: below the country's absolute poverty line decreases significantly and the distribution of incone doe's not becomé:"more unequal"as "result of increases in GNP:

3/ See, for instance, Hollis chenery et. al., Redistribution with Growth: Policies to Improve Income Distribution in Developing Countries in the Context of Economic Growth (Oxford, World Bank and the Institute of Development Studies, "University of Sussex, 1974); and Gerald M. Meier and Dudley Seers (eds), Ploneers in Development (Washington D.C., World Bank, 1984). In this latter publication the World Bank sponsored ten pioneers in the concept and practice of economic development to recapitulate the status of economic development today vis-a-vis what it was some thirty or forty years back. 
10. With hindsight, therefore, human dimensions must be accorded a central place' in development planning and inanagement. At the Khartoum International Conference on the Human Dimension of Africa's Economic 'Recovery and Development, it was emphasized that the issue is one of people planning and assuming responsibility for investment activities, carrying them out and making them profitable. "Development is about man and if it is to be genuine, man should become its active agent and not passive beneficjary" $4 /$ This undertines the fact that public participation implies not only the right to exercise inalienable human. rights but also individual obligations to and sacrifices for the common good of the society.

\section{Concept of Development Management}

11. The concept of development management deals with the managerial and administrative aspects of developpent planning. In the context of public participation, this would encompass the institutional, organizational, managerial and administrative functions which are essential for the successful implementation of development plans. Development planning does not take, place in a vacuum." Rather it takes place within specific socio-cultural institutions and value systems. Thus, factors such as existing land tenure systems, society's attitude to property ownership and profitability, traditional leadership institutions and responsiveness of cultural factors to planned changes, invariably affect the implementation and outcome of development plans. The interaction of development managers with a cross-section of society will facilitate the smooth transformation of existing socio-cultural institutions in accordance with changes which are inherent in development planning. Knowledge of the existing characteristics of the socio-cultural institutions would make the job of the development manager or administrator much easier.

12. In the same vein, organizational issues include decisions on functions, the clustering of these functions to derive a functional organisation chart in which harmonious relationships could be established among the bureaucracy of development plans and the general public. Organizational issues also deal with the broad policy question of the location of responsibility for national planning within the igovernment bureaucracy or machinery. There are a diversity of organtzational forms in practice in African countries. Responsibility, for development planning could be vested in a Ministry of Planning, Ministry of Finance and Planning, or in a National

47 UNECA, The Khartoum Declaration, 5-8 March 1988 op.cit. P.3 
Planning Commission. Each country has its own reasons for prefering one organizational form over the other and public participation may well be one: of the reasons in the policy decision making process. The development management concept argues that organizational issues must be carefully considered in the formulation of development plans. organizational design must. be commensurate with the requirements of the development plans of each country. is

13. The managetial and administrative aspects of development : management must be seen within the institutional and the organizational paxameters of development planning as indicated in the preceding two paragraphs. More specifically, the job of the manager and the administrator is essentially to harness and direct human resources in the formulation and implementation of all activities in the development plan. In this regard, managers and administrators include politicians, specialists in development planning methodology,. statisticians, economists, sociologists, agronomists, financers, private and pubitc enterprise officials and individuals whose activities will be affected by development planning. The success of development planning depends on the capacity of all these managers to imake effective decisions and to motivate the employees and the general. public to commit themselves to the attainment, of the planned objectives of agricultural, industrial and social developrent. The development management concept postulates that the design, formulation: and implementation of development plans must take into account the availability, capability and capacity of local personnel: to sustain the management of all aspects of a development plan.: Iraining and the continual development of local expertise in the management of all aspects of the development process must be consideredias the cornerstone of the concept of development management.

14. The incapacity of Africa's economies to respond appropriately to exogenous economic shocks such as fluctuating commodity prices and dwindling foreign exchange earnings has been attributed not anly to shortcomings in development planning but also to the gross mismanagenent of both the, private and public sectors. The latter being the leading sector, has had to bear the brunt of this accusation for shoddy management of the development process and programmes. At independence in the early la60s, civil servants did not consider themselves as managers but as administrators. Management was then associated with commercial enterpises. This misconceptual dichotomy has had adverse repercussions on the partnership that should have existed betwee. the private and public sectors in the management of the national econony. In the private sector, firms have resisted the demand for workers' participation in management and in the public sector civil servants have hitherto not considered the private sector as partners in national economic management.

15. Hotwithstanding, the obvious relations since independence and changes in international economic the increasing complexity of the 
demands of the population and sophistication of service institutions, government administrations, in independent Africa have the tendency to cling to the legacy of anachronistic administrative traditions which were designed for colonial exploitation rather than for development. Thus, like development planning, development management in Africa has, partly for historical reasons, been slow to re-adapt to changing ecconomic environments. The turbulence of the world economy, the debt crises and deterioration in living standards require flexible, approaches to the resolution of management problems. pevelopment plans: need to be correlated with a country's capacity to manage developmental programmes in an ever changing environmetit rather , than immutable blueprints that must be implemented even when it is obvious that the country will not be able to mobilze the required resources without adverse consequences for the population. A review of recent experience in strategic planning and managemerit indicates that management practices, particularly at the executive level, are undergoing substantial changes in response to accelerated pace of change in global levels of competition and resource mobility. Public institutions are, therefore, facing new challenges as they at tempt to support social changes that are concontiant with economic change. Bureaucratization and centralization tendenties of the 1960 s have given way to strategic management which', inter alia, employs a planning process that is issue-focused, creative, selective, opportunity seeking, highly. interactive and exphasises leadership and delegation within a strategic framework: $5 /$ planning and management should be regarded as integral processes in which the degree of public participation determines the quality of performance of the development activities of a nation.

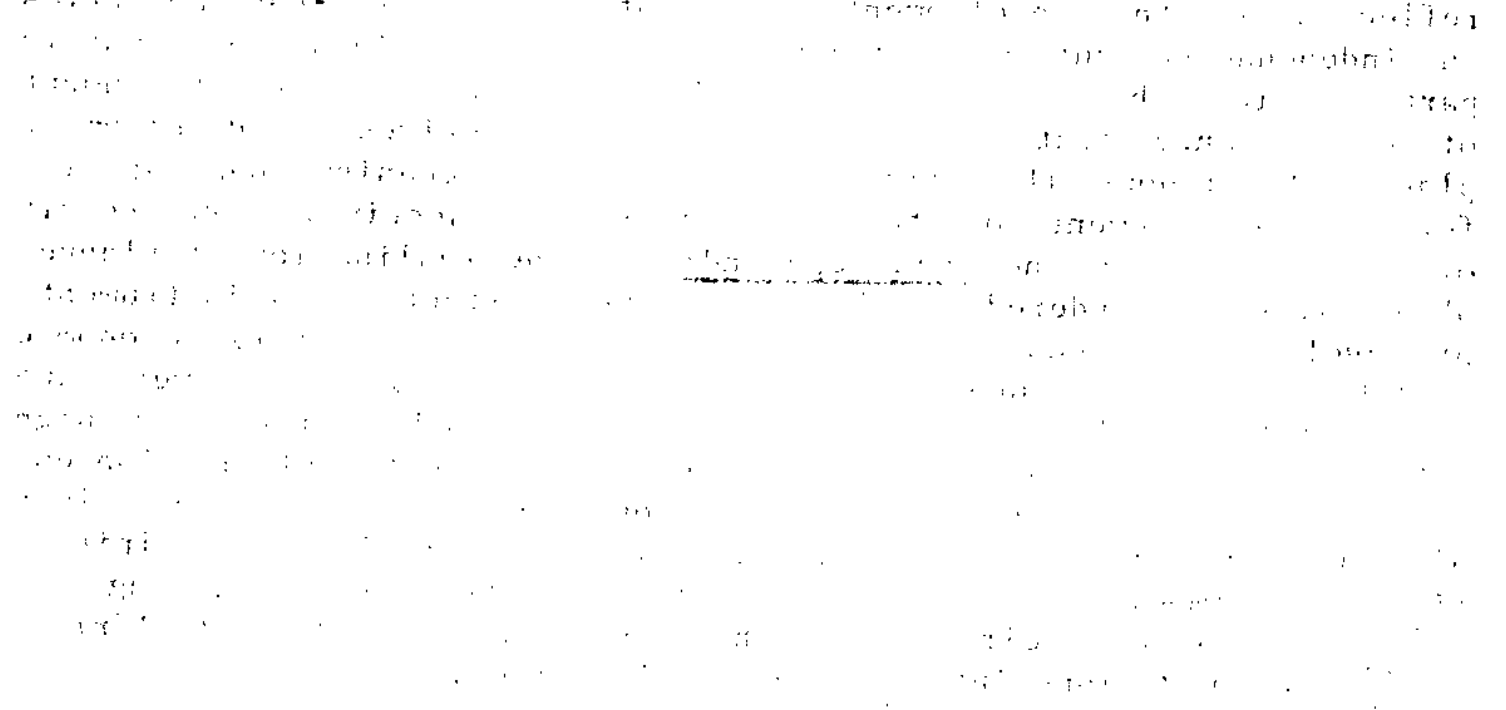

5 I... See, for Instance, "Nagy Hanna, Strateglc Planning and Wanagement: $A$ Review of Recent" Experience (Washington, D.C., The World Bank Staff Working Papers Number 751, 1985) for details on the concept and practice of strategic planing and Managetient especially in Private Sector organizations. 
ECA $/$ PHSD $/$ PAM $/ 90 / 4(1,2)\left(\mathrm{p}_{1}\right)(\mathrm{d})$

Page 8:

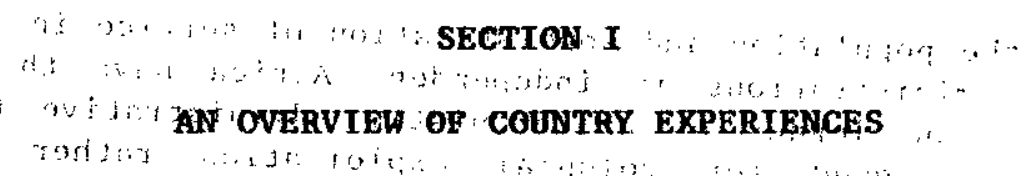

A. The Iosues th Perspective

16. Virtually all Independent African cauntries have accepted public participation in aeveloptent planning and management as the sin qua non for sustalned social and economic development. In order to meet the risfing expectations of the population for a better life on independeftce? Afrlcan governments embarked on the preparation of 1ong-term ${ }^{n}(1-20$ yrs), medium-term, (1-5 yrs) and short-term (13 yrs) thational development plans; annual! budgets; development projects; and participated extensively in commercial activities and enterprises which were best undertaken by the private sector in Industrialised countries. Development Plans in African countries differ in terms df magnitude of objectives s priorities and comprehensiveness; "extent of the pubilc sectar vis-a-vis private sector; the structure and style of the planning agency; and the , praxis of planining philosophles, between, planned economy based on the Soviet Union prototype and the free market protatype of the Adan Sinth-School.

17. The inadequacy of resource management capacity and direction on how to achieve objectives and targets of plans constitute constránts in planning and management in practically all African countries. Free education, free medical services and subsidised food production are, for example, plausible objectives which were reflected in the development plans of several African countries on Independence but have never been achieved. Similarly, public participation which had contributed decisively to the attainment of independence featured as one of the objectives in development plans but without the articulation of the mechanism and capacity for the achievement of this well-founded objective. The result of these lapses in the modus operandi for the realisation of planned objectives has rendered development plans ineffective as instruments of development. Thus it could be argued that the positive economic growth rates experienced in Africa up to the mid 1970 s were due more to fortuitous circumstances such, as good weather and high prices of export commodities rather than to national development plans and good management of the economies. At the first flush of endogenous and external economic shocks, including a precipitous fall in commodity prices, the flaws in development planning and management become self-evident and the economies of most African countries would plung into socio-economic crises.

18. Coupled with the lack of articulation of the mechanism and the capacity to attain planned objectives, the tasks of management of rapid econotnic changes overwhelmed the capacity of the colonial trained civil servants. All responsibilities for the extended commercial activities of the government naturally devolved on civil 
servants, especially senior administrators who are advisors on formulation and implementation of government policies. In effect, administrators. who had been trained in governmental processes that ensure the malntenance of law and order and the colfection of tax revenues, were called upon at independence to assume full responsibility for the management of socio-economic plans which required new skills, new approaches and new attitudes. In the circumstances, the challenge of independence and the development planning and management problems it brought made it difficult for any meaningful administrative reforms to be instituted during the nation-building years of. independence. This, then, ought to be the perspective background against which to review African countries. experience with public participation in national economic management for sustained development.

19. Since the late 1970s, when the creeping problems of economic planning and management came to a head, African leaders from all walks of 1 ife have been preoccupied with the quest for strategies which would turn around the dismal performance and bleak economic outlook of the continent in the direction of speedy recovery and sustained development. It has since been realised that public participation as a critical factor in overcoming the contemporary economic problems should not be perceived in a vacuum but in the context of political and governmental systems and structures, on the one hand, and the resource base and capacities of the productive forces of each country as well as the ramifications of the mobilization of external resources for Africa's econotic recovery, on the other hand. In this regard, "the public" includes not only the citizens and other inhabitants of each African country but also the taxpayers in non-African countries which are already or could become partners in the development efforts of African countries. The fnancial magnitude and pattern of financial involvement of the domestic and 'external' public in Africa's economic recovery is shown in Table 1.1 for the period 1986-1990. 
Table 1.1

\section{FINANCIAL. IMPLICATIONS OF PUBLIC PARTICIIPATION IN AFRICA'S} ECONOMIC RECOVERY PROGRAME 1986-1990

(in million Us dollars)

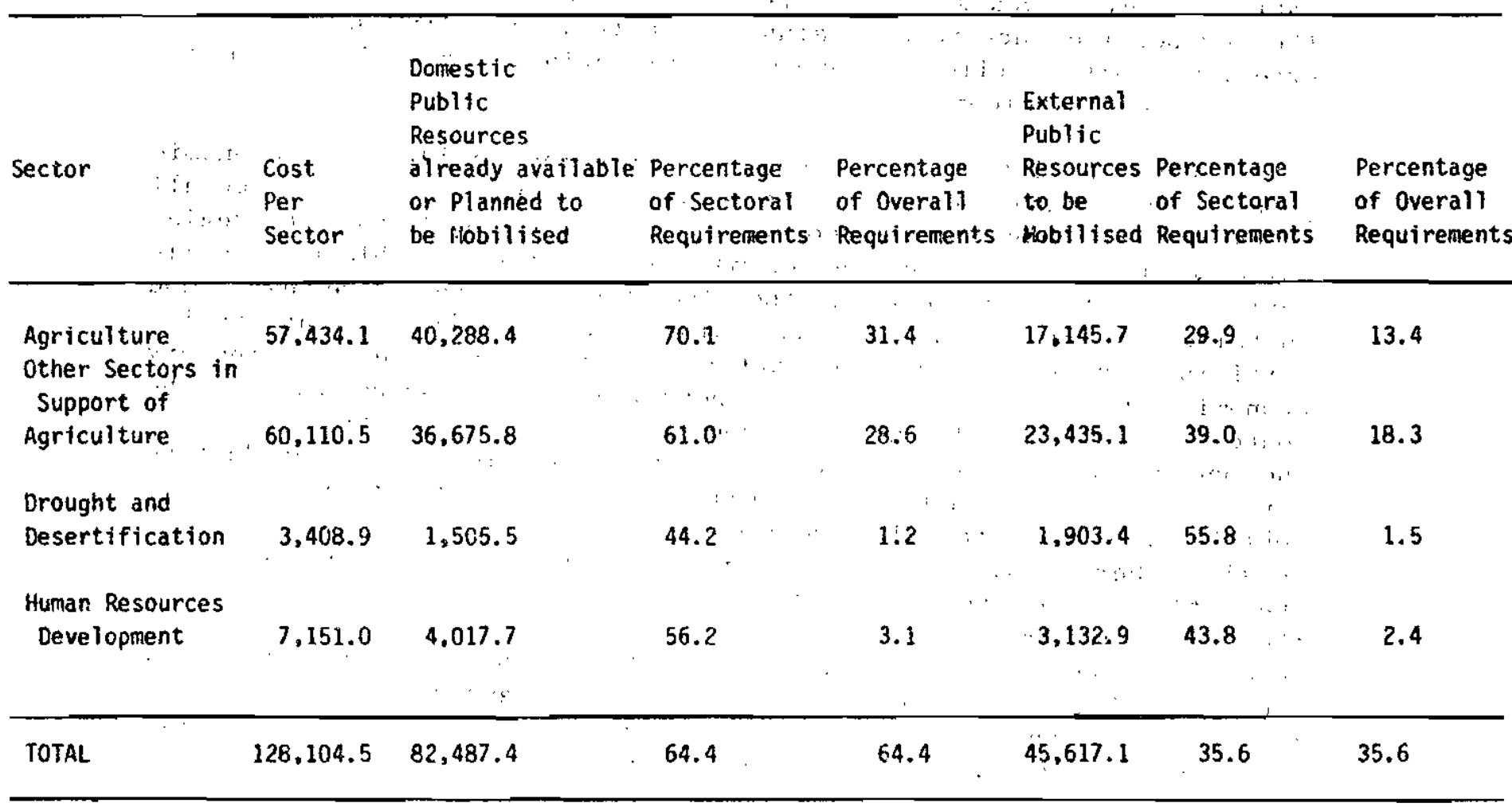

Source: Adapted from Africa's submission to the Special Session of the United Nations General Assembly on Africa's Economic and Social Crisis as adopted by the first extraordinary meeting of the ECA Conference of Ministers, held at Addis Ababa, on 28 and 29 March 1986 and the Fifteenth Extraordinary Session of the OAb Council of Ministers also held at Addis Ababa on 30 and 31 March 1986 Tables $1-5$. 
20. The $35.6 \%$ financial resource gap in Table 1.1 to be made up from taxpayers of non-African countries should be a source of concern. This foreign resource gap could be critical to the success of Africa's economic recovery programme notwithstanding the fact that the bulk $(64.4 \%)$ of the resources would come from domestic or internal sources that is, from the domestic public participation in economic activities. Table 1.1 figures, therefore, raise more questions than provide answers to the African economic problematique. With hindsight, the mid-term UN-PAAERD review cautions, inter alia, that even though the international community has committed itself to an increased level of both bilateral and multilateral financial assistance to African countries, further improvements are required in the quantity and trend of resource flows to Africa. For instance, whilst net rcsource flows to Africa increased from $\$ 17.9$ billion in 1985 to $\$ 19.9$ billion in 1986 and $\$ 22.9$ billion in 1987 in nominal tering, measured in real terms, resource flows to Africa were lower in 1936 and 1987 than in 1985. Statistical annexes to the UN-PAAERD riic-teril rovicw report of the U.N. Secretary-General depict the sam? scenario of inadequate and diminishing resource flows to Africa. 6/ Needless to reiterate the fact that governments in non-African ccuncries would not ignore the interests of their taxpayers in order to meet the development requirements of African countries. Every country in the world tends to give priority to the needs of. its own citizens. It is therefore unrealistic to expect endless aid frow the taxpaying public of non-African countries or to expect consumers of Africa's commodity exports to pay higher prices and be worse-off even if they can pay less and be better-off in their. standard of living. These contemporary realities of international econcmic relations should be realized. The social and economic changes currentily underway in Eastern Europe add yet another dimension to the uncertainties of external public participation in Africa's economic recovery and development. Thus measures to boost domestic rather than external public participation will be decisive in Africa's efforts tovards sustained socio-economic transformation and development. $\Lambda s$ it is known, commitment of African leaders to public participation in development is unequivocal but the measures to operationalize this noble conviction are still in the making. This report and conferences such as the Arusha International Conference. on Popular Participation (12-16 February 1990) demonstrate the seriousness of African leaders' conviction in public participation as an instrument of economic recovery and development.

6/ See UiT General Assembly doc." A/43/500 of 10 August and $\bar{A} / 42 / 500 /$ Add. 1,18 August 1988. 
ECA/PHSD/PAil/ $00 / 4(2.2)(\mathrm{i})(\mathrm{d})$

Page 12

21."A country-by-country review of public particlpation in all the 51 independent African countries would require much more space than is available in this report. Table $i .1$ is an aggregation of the quantitative resource cost of internal and external puhlic participation in all. Africa's economic recovery. Available empirical evidence $7 /$ hased on a sample of African and latin American countries could aiso provide the 'contours which could be extrapolated and tentative inferences" drain on the experiences of several African cointries. This could be used as"a ba'sis for the articulation of future strategies for public partlcipation in development management in Africa.' Since about '91.8\% of the finaticial' resources of the African Priority 'Prógramme for 'Economic kecovery (APPEI) were earmarked for agricultúre and other sectors in support of agriculture, anc ahout $55-75 \%$ of Africa's poputation reside in the countryside, it would be appropriate to review participation at the in-country project level by taking empirical information from the random selected countries.

22. In Africa, women play a significant role in food production. The emptrical evidence "being reviewed covers' seven countries inclucing Ghana, Kenya, Lesotho, Higeria and three Latin American countries. The empirictl scudies urderline, inter alla (a) except in liorthern Iligeria," that : women tend" to have conrlete equality regarcing participation in baslc agricultural production although in lorthern Ghena and horthern Higeria, both Huslim "areas, the rate of complete equality appeared' to' be lowest; (b) the 'low rates of women in decisionmaking in five of the countries tetids to be thened somerhat by greater participation; '(c) in Bolivi'a' and 'Perit women tend to have nore decision-makitig power on matters,"such as, the decision to join a cooperative or : obtain credit!' In' some of the countries where credit is tied to landholding as collateral, males tend to dominate the decision to "negotiate for credit facilities; (d) famers especially small farmers, are 'risk aversive: a subsistence farmer, would, for instance, opt for a guaranteed small crop yield for himself and his family rather thàn go in for a higher yield which has a bigher risk of failure; and (c) planners generally tend to ignore or underestimate the fact that in acricultural production activities,

77 Elliott P. Horss, John $K$. liatch et al, strategies for Small Farmer Development: An Empirical Study of tural Development Projects in The Gambia, Ghana, Kenya, Lesotho, Iigeria, Bólivia, Colombia, lexico, Paraguay and Peru. Cp.cit. 
the participotion and decision-making powers of women could be crucial to success. In essence, therefore, the comparative role of men and women in decisicn-making shouid be taken into account in project design. $\underline{8} /$

23. Examples of farmer contributions in the determination of activities and the ways in which they are implemented could be summarised in the following brief cases of projects with high and low levels of local injolvencnt in the identification and design stage of a development project. (i). Tiv Bains/Farmer Association/Nigeria: Gover ment credit to farmers was tied to political loyality, the Tiv leaders and farmers developed a savings and loan programme conristing tof tocal banks (hamo). The concept spread rapidly through tirce Tiv Diviesens, and became the basis for the effablis!ment of a rulti-tiered Farrers' Association for improving of agricultural rroduction in cooperation with government extension workers;" (ii) the Mxer Vegetable"Schene/The Gambia (MVS) grew out of women's initiative to participate in The Gambia Cooperative Unich. Frovcoosentives for wonen were set up to test and implement a technologica! package and so began the institutionalization of women's traditional role as innovators in Gambian agriçuture. A1l in a11, local small farmers could be involved in the generation of useful project ideas; communication and refinement of projeci j.ders in the light of local experience; local people and project staff colid also experinent with innovative ideas or packages; and involveiant in decision-making. All these empirically; identified rolas in the participation process could be significant in the dosign phase of a project if the project is area-intensive, the interveniag cgent holds a series of progress meetings with local leadeas ard farmers embracing farmer participation and control over deciulone, famers themselves work as partners

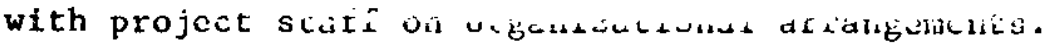

24. Local participation during project implementation and management could be most effective it there is reguiar dialogue of farmers with project staff; there is firmer control or sharing in project decision-making in. so far as they affect management in the farmer's locality. The farme $\mathrm{h}$. Ts opportunity to test new technology introduced; and the farmer controls or shares in the management of project activities in his local area. Local participation could be quite low if the local peopte find out that the project staff tend to doninate decisicr-making in project design and management.

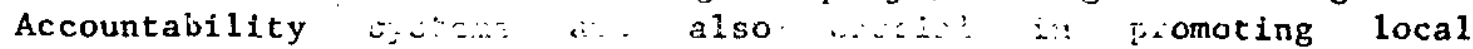
participation. Training, cffective two-way communications systems and use of para professionale such as national agricultural extension agents could all improve farmer active participation in development projects.

8/ Ibid. E11iott R. Morss, John K. Hatch et al. pp. 59-61. 
25. Resource comritment in public participation is one of the areas usually disregarded. For a rounded definition of participation, resource:commitment by all the parties who will also expect to share benefits is essential. Thus in the empirical data $9 /$ under consideration the following Table 2.1 illustrates circumstances under which farmers will be willing to commit their time and money to a project. : .

\section{Table 2.1}

\section{STANDARDIZED SMALL FARMER RESOURCE COMMITMENT BY DECISION-MAKING RESPONSIBILITY}

Major Decisions Made by:

Project

$\underline{\text { Staff }}$

Item

\section{Average}

Farmer, Resource

$-.444$

$-.099$

Commitment :

(Standardized)*
Farmers

Farmer and

Project Staff
Standard Deviation

Number of Project Cases

$\begin{array}{ll}.817 & .645 \\ & \\ 14 & 8\end{array}$

*Significance. Tests for Mean Differences. The number under "Major decisions made by" is the t-ratio statistic for the test of differences between means (averages). Given the size sample, the t-ratio must be greater than 2.086 for the difference to, be significant at the .05 (i.e.5\%) level, or the level of confidence is $95 \%$. Thus:

Project vs Shared

2.424

\section{Shared vs Farmer}

1.301
Project vs

Farmer

.979

Source: Adapted from Elliott R. Morss, John K. Hatch, et al, Strategies for Small Farmer Development op.cit. p." 85

97 Ibid. p. 85 . 
The statistics in Table 2.1 suggest simply that farmers àre likely to be more willing to commit their time and money (resources) to a 'project, if they and the project share deciston-making responsfbilities than if this function is controlled either by the project or the farmer alone. The implication is that farmers would make significant resource commitment if they themselves have a voice in all aspects (design, implementation, monitoring, and management) of a development project than if the government or foreign assistance agency were to go it ali alone and then impose the project on the farmers... Each African country has had experience with development projects that failed essentially because the local people's ideas were disregarded or not sought. In the circumstances, local commitment of . peoples' time and finaucial resources could not be forthcoming. These micro-level project experiences could be extrapolated to the national or macro-level and the outcomes would be' just as negative, albeit perhaps cumulatively negative in national socio-econotaic development if the majority of the projects in the nation follow the same non-participatory methodology of planning and management as illustrated here.

\section{B. Changing Perceptions and Re-orientation of Development Planning and Management}

26. In the face of excruciating socio-economic crissis, it is evident that virtually all African countries have drawn instructive lessons from the failure and poor performance: of past development plans and economic management experiences. It has been realised, for instance, : that plans that ignore the: influence of market forces and incentives or assume that internal economic policies could be insulated from the behaviour "of external economic forces cannot succed in achieving expected results. It has also become evident that goveroments' financial and "administrative capacity to handle public enterprises and other social responstbilities should be rationalised and restricted to those activities which the state can manage effectively and without leakages in the utilization of scarce resources. Preoccupation with grandiose plans and objectives without the financial and managerial capacity to carry them through has given way to less over-ambitious and pragmatic approaches to $\therefore$ development planning. The role of the government in directing the - economy still remains crucial but the management limitations of the government have also been recognised.

. 2 27. Al1 the countries reviewed seem to have made a new beginning in the perception and rearientation of the role of government in political-economic matters." The thrust would seem to be in the direction of creating the framework and the enabling environment for individuals, the private and informal sectors to spontaneously participate with the government in the task of economic management for development. This is not an easy task.

28. The new perceptions and reorientation of the enabling environment to foster spontaneous and hence effective public 
participation in development in various African countries could be classified as hereunder:

(a) Peaceful coexistence as precondition for public participation in development has been intensified by all African countries. Notwithstanding, the outstanding hotbeds of disputes in some African countries, recent peace initiatives in Angola, Ethiopia, Mozambique, Sudan and the independence of Namibia as weil as the cracks in the system of apatheid in South Africa are pointers to the acknowledgement of the essence of a peaceful enviroment as a precondition for public participation in development management.

(b) Political process as the basic instrument for public participation in development has also been reaffirmed in countries with civilian and military regimes. There is increasing consensus among African leaders that freely elected representatives of the population would reflect and promote the genuine development priorities of : the nation.: This would enhance the confidence of the people in their government. It cannot be gainsaid that lack of confidence in government has been one of the main causes of corruption and mismanagement of the economies of various African countries.

(c) 'Planning with the People' $10 /$ has been adopted as the motto: for people participation in development. In 1976, the then President of Botswana, late Seretse Khama, gave the mandate for planning with the people in Botswana based on the premise that planning was not the prerogative of only civil servants or technocrats but the concern of all Botswana. Officials were, therefote, to keep in touch and consult with their communities on the whole range of government policies and programmes given that the target of government efforts was the improvement in the quality of life of the people. In 1983, His 'Excellency, Arap Moi, the President of Kenya, announced also that: the Kenya government was fully prepared to launch a new'strategy which would devolve development planning and implementation to the districts $11 /$ in order to ensure the participation of the grassroots population in national development.

10/ See Dolf Noppen," Planning with the Perple in Botswana op.cit. p.40.....

11/ Commonwealth Secretariat, "Decentralisation in Kenya" in Decentralised Administration in Africa: Policies and. Training Experience (London, Jan. 1989) P.75 


\begin{abstract}
... Thus planning with and by the people has come to be accepted as the cortherstone of developwent management in African countries.

(d) Decentralised adminietration could improve public management and delivery eyzters as, well as contribute to the enhancement of puilic participation in development. African countries held two worksliops bider the auspices of the Management Development Progranme of the Commonwealth Secretariat in 1986 and 1987 and, among other things, argued rightly that although decentraised administration was not the cnly stratcgy to ensure public participation, since iadepencence effertz tu bring the government closer to the prople and to icmocratize cievilopment have been guided by the cbjectives to (i) involve the population directly in projects formulatior and management; (ii) transfer decision-aking to the relevant locality; and (1ii) allocate human resourses according to need. $12 /$ The methods used to attain shese objeciives have differed from courtry to ccurtry but the basic premise of democratisation of paiticpatic. in developrent has been identical.

$i$ is

(e) Privatization and Jolr: Ventures with governments have also recelve attention or vartous African countries. Although it cou'd $3 a$ argued that the resort to privatization policies in Afric. snaridted frca the IMF, the World Bank and some bilaterai futics ic nust be admitced that consistent fi:iarcial ad ingement problems of stateowned comercial enterisis lad bacene a serious oource of public sector defizits with suplications for the current excruciating extortal scht crisas of African countries. In the circumstances, African governments themoelves, have had to re-eramine the efflciency of the public sector as a whole with a view to rofrming the public enterprises to make then roal partaers in national development. Early experience of privatication cues in the developed countries suggest that technical difriculies could be as constraining as political factors $13 /$ and as such privatization ray not be the panacea for ccorcaic recovery and development.
\end{abstract}

12/ Ibid. Commonwealth Secretariat p.4

$13 /$ : See Nicolas van de Walle, "Privatization In Developing Countries: A Review of the Issues", World Development, Vol. 17 llo. 5, pp. 601615, 1989 (Great Britain, Pergamon Press, 1989). 
(f) Informal sector and non-governmental organisations have also been encouraged to participate in development management. The government alone has limited capacity to generate and provide employment to the ever increasing population of young people who enter the labour market each year. Thus, it could be argued that the trend towards the "operationalization of the concept: of public participation since the mid 1980 s has been to move towards the creation of conditions and the enabling environment which would stimulate individual and collective initiatives in employment generation and contribution to national development in partnership with the government: A review of the impact of this trend is the subject matter of the ensuing paragraphs.

\section{c. Impact of Fublic Participation on the Development Process}

29. Across the length and breath of Africa, the clamour for governiments to provide more and more goods and services for which Individuals cannot afford to pay or provide for themselves has become louder than ever before. The pre-independence promises of governments to provide free social services and employment for al have come home to roost in the form of economic stagnation, national budget deficits, debt crises, chronic balance-of-payments disequilibria, and the deterioration of living standards and conditions of the vast majority of the Afican people especially workers, peasants, women and children. Although this dismal scenario could be attributed to the vicissitudes of the global economy in terms of etratic demand and fluctuating prices for Africa's commodities as well as unfavourable terms of trade, the partial responsibility of some of the domestic policies of African countries for the current crisis of development should not be swept under the rug. "The neglect of rural areas, pervasive corruption, excessive bureaucratisation, distorted national priortties, misplaced reliance on foreign capital $14 /$ and the lack of perspective in the promotion of public participation in the political, social and economic dimensions of development plannirg and management have all contributed to the current social and economic crises.

30. The revival of public participation as a critical factor in economic recovery and development reflects the determination of

14/ Bdde Onimode (ed), The IMF, The Vorld Bank and the African DeBt: The Social and Political Impact Vol. 2, (London, The Institute for Afrtcan Alternatives, 1989) p. 192 
African leaders to involve the whole population in finding solutions to the current economic crisis. The people must themselves determine the most appropriate path to achieve sustainable social and economic development. The initiatives: enumerated in paragraph 19 of this report under "Changing Perceptions and the Re-orientation of Development planning and Management" demonstrate the significance which African governments": attach to the renaissance of interest in and commitident to the concept and operationalization of public partictpation: . The decision to hold an International Conference on Popular"Participation' in the Recovery and Development Process in Africa 15/ 18 a case in point. It underlines the commitment and serioboness of the African governments, peoples and the international communtry to involve the whole population in the development management efforts of the government in order to speed up the econoinlc recovery and development process.

15/ This Conference which was held in Arusha, Tanzania, 12-16 February 1990, arose from discussions between government and nongoveriment organtzations (NGO) representatives at the September 1986 mid-term review of the implementation of the UN-PAAERD by the U.N. General Assembly New York, and the ECA Conference of Ministers responsible for economic development and planning adopted resolution 664(XXIV) at its Fifteenth Meeting/Twenty-Fourth Session of the Commission Supported the convening of the Conference and urged member States to support and actively participate in the Conference. 


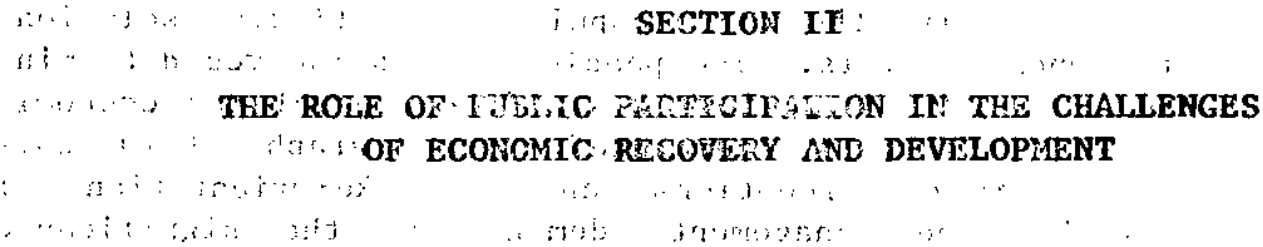

31. The emerging consensis in Africa now is: that popular public participation with the lgovetnentuin grappling with the vartous probletis of developintert : planting and. management would contribute immensely to the speedy econonic cecovery and development of the continent. 'In : this regard, the U.N. Geraral Assembly in adopting the report "of the $A \mathrm{~d}$ har. Connttere of the Whole of the General Assembly on the Review ard Appretsal of the UN-PAAERD, unanimously endorsed the viow thr." "lu participoticis peple in the recovery and development process: siould ccntinue to $\%$ b broadened and made more effective, particulariy throuch promoting increased access to development rescurces and benefits, creating favourable conditions for decentralized decision-making, encouraging greater entrepreneurship at all levels and promoting individual initiative and private enterpriee". Sisequenty, in the Joint statement on AAF-SAP (April 1989) by African Ministers responsible for economic development and planning and finance, it was underlined that "in the formulation, implemertation and monitoring of the AAF-SAP at the national level, the entire pop'lation should be fully involved. To this effect, each country should take appropriate measures to create the necessary enabling environment for effective popular participation thereby consolidating and deepening the process of self-reliant development." $16 /$ The role of public participation in the challenges of economic recovery and development could therefore be perceived against the background of the concerns, convictions and comitment of African leaders.

32. The specific objectives of the Arusha International Conference on effective popular porticipation in development were to "(a) provide recognition of the role of people's sportaneous participation in Africa's recovery and development efforts; (b) sensitize national governments and the iaternational community to the dimensions and results of and benefits to be derived from the contributions of people to their cwn self-develofrant; (c) identify obstacles to

16/ See E/ECA/CM.15/6/Revs 3 Anne: II on Addis Ababa Joint Statement by African Ministers of teromomic platining and Development and Ministers of Finance on the "African Alternative Framework to Structural Adjustment Prem for sơciomeconomic Recovery and Transformation para. 7! Adels Ababs; Sthtopia! 10 Ap-i1 1989. 
people's participation in development and define appropriate approaches for the promotion of popular particdpation in development policy formation, planring and implementation of development programmes; (d) recommend actions to be taken by governments, the United Nations system, the public and private donor agencies, in building an enabling environment for effective popular ferticlpation in the development process which motivates people and their organisations to undertake self-reliant development initiatives; and (e) (propose indicators for the monitoring of progress in facilitating people's participation in Africa's development". The modus operandi for the realisation of the objectives enumerated here might differ from country to country, although African countries share, certain common economic and social characteristics of underdevelopment.

33. With the determination of African governments to give new push to agricultural development as the anchor-sheet of food security and lagro-based Industrialization, all countries are adopting comprehensive polfcies for the full and effective participation of the people in agricultural development. The imf:ovement of the working environment and living conditions of women and youth in the rural areas has become a priority. Measures are being undertaken in each country for the people to participate actively in increased food production: arable land development and land improvement; animal and., Ilvestock product development; mechanization; storage and marketing; agricultural research and extension; water resource management and low-cost irrigation schemes; reafforestation programmes and.idrought and desertification control. 17/ In the ECA Economic Report on Africa 1989. the improved performance of the food and agrifulturel. sector in 1988 has been attributed generaily to good weather acrces the continent and particularly to supply response of the fortis fopulatton to incnrtive packages introduced by recent policy:, reforms.

34. The, problems of women espectally rural women as the major producers: of food and also pastoral nomads and semi-nomads who are

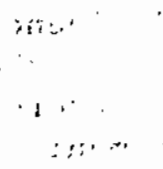

17/ See $0 . \mathrm{U} / \mathrm{L}$ CY/ZXV/Rev. 2 and E/ECA/ECM.1/1/Rev.2 on "Africa's Submission to the Spental cnection of the U.N. General Assembly. on. Africa's Economic and Social Crisis" as adopted by the firot extraordinary: meeting of the ECA Conference of Ministers, held at Addis Ababa, on 28 and 29 March 1986 and the Fifteenth extraordinary sesaion of the OAU Council of Ministers, also held at Addis Ababe on 30 and 31 March 1986, p. 14. 
the main participants in the svestock stbsecto: are being addressed more forcefully. Thorc $j:$ not a chteft of cmphesis from large-scale

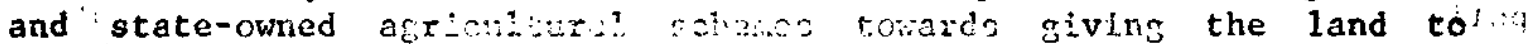
the actual tillers and promotis maliholder agriculture for the

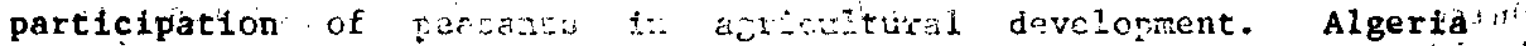
is "reported $18 /$ to we one of the rocities where people-centred agricultural reform lice frodebly gone the furthest. Whilst in countries like Ethiopic; the zovernient is implementing vast and innovative reforms to thake tise countryale more conducive to increased productivity of the people through greater participation in agricultural activities:

35. Peoples participation in manufacturing and processing Industries in Africa have continued to be conetralnee by structural deficiencies and the sluggish progzess rade in the inprovenent of this sector. Perhaps only Maurittus has as itpresive record of industrialization whilst Botswana's astounding economic growth could be attributed to the upsurge of $a$ dianond boom which has nonetheless attracted a number of industrial establishtuents in recent years especially from South Africa: Reorientation of inclustrial policies in the direction of projects with Ic capital infcinsity and based on the avallabllity of local noturel zosures enioments with backward and forward linkages would incrense the rate of public participation and the accrual of social berefits from triustrialisation. The improvement in the percention of the aricultural sector would boost Industrial developirant?

36. In the social services sector, tha altady very low income levels of the people impose a iinft on the taxable capacity and also on the ability of he foptesion to coniribute substantial financlal rescircas dirsctig to the resorsy and development

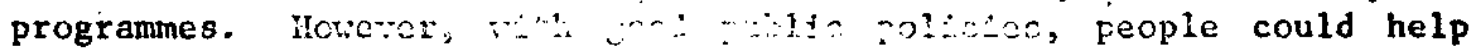
the government to reduce pulic expensitute dil bealth care, education

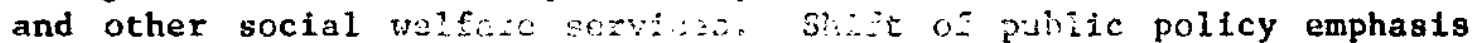
from free curative rea?thare to Cortunty Health Care (CHC) in which each comunity taks responsibility for the maintenance of

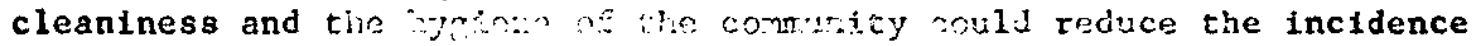
of disease and thus rciuce in curative modical bili of the government. Health educationi on a groid cealo could also reinforce the CHC or Primary liarit. Cre (PriC) ctosts of the communtey.

18/ See ECA Economic peport on Africa 1939 (Addis Ababa, April 1989) pp. 12-15 for a generat revicw of the performance of the food and agticultural sector in Africa. 
Responsibility for national education could also be shared between the government, the community and individuals. Government policy could provide for the establishment of private schools without lowering the standards of scholarship. Communities could establish schools with financial and material assistance from the government. For instance, communities could be encouraged to provide labour and local building materials for community schools whilst the government provides and pays for qualified teachers, etc. Similarly communities could be made responsible for the solution of social problems. such as juvenile delinquency, neighbourhood crimes, alcoholism and drug abuse. The Ministry of Social Welfare Services or some other government institution could launch community development programmes to promote healthy and responsible behaviour in the nation. One of the intrinsic attributes of man is to feel delighted to be associated with contribution to public welfare in the field of education, health and charities. For this attribute to bloom and flourish in any society, there must be absolute and demonstrated confidence in the management of the available resources, no matter how meagre these resources may be. In this regard, the sombre realisation that the current economic crisis has impelled the African public to raise questions about the propriety and probity of those charged with responsibility for national ecönomic management should go a long way to encourage greater democratization of participation in decision-making processes which affect the welfare of the public. With the intensification of genuine commitment and measures to involve the latter in decision-making processes of planning and management of the national economy, people would be more willing to make sacrifices for the health of the community, their own education and that of their children, and the eradication of social problems so as to create a conducive environment for socioeconomic development.

37. Popular public participation will lead to an increase in the productivity of all the workers in all sectors including the informal sector of the African economies. People will take pride in whatever they do. Those who are employed in the formal sector and the selfemployed would have the incentive, through genuine participation, to commit themselves to the requirements of whatever they may be doing in their own and in the national interest. With increased productivity, the per capita and hence the national income of each country will increase; there will be increased availability of goods and services; and the overall standard of living of the population; and above all, Africa will become less and less dependent on the outside world to dictate the pace of the development of the continent.

38. Internal mobilisation of resources for development will also be improved through public participation for instance, in the formulation and implementation of taxation system and the allocation of expenditures.

39. Similarly public participation in external resources mobilisation would facilitate the realisation of the 35.6 per cent foreign 
component of the resources required under the UN-PAAERD. Public participation in the mobilization of external resources should be perceived from the angle of (a) the foreign governments as the accredited representatives of their electorates; and (b) the taxpayers of the countries from which Africa hopes to mobilise the 35.6 per cent of its UN-PAAERD requirements. Public participation will thus make it easier for the government to negotiate with foreign countries from a position of the strength of the people. Public participation in the development process could therefore make a nation great. This would attract the confidence of other nations and enhance external mobilisation of resources to close the gap between avallable domestic resources and the resources required for the realisation of the aims and objectives of development planning and management in African countries.

40. The whole population will become much more aware and appreciative of the vigorous demands of development management if all the actors fn the economy have the opportunity to participate in policy decistons, plan formulation, implementation and management of the economy. Public participation should therefore be considered as the sin qua non of successful development planning and management.

41. In the Arusha 1990 African Charter for Popular Participation In Development and Transformation it has been rightly observed that popular public participation ought to be seen as both a means and an end. It is an instrument of development. It provides the driving force for collective commitment to people-based development processes and people's willingness to make sacrifices and expend their social energles in the execution of development activities. As an end in itself, popular public participation is the fundamental prerogative of the people to fully and effectively participate in all decisions which affect their lives at all levels and at all times. The accredited representatives of the people need to appreciate the fact that the people are Africa's most important resource.

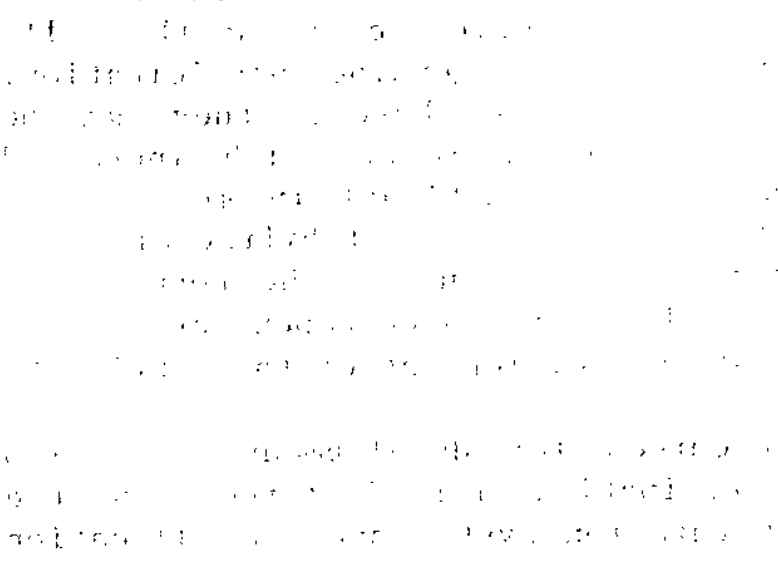




\section{SECTION III}

\section{STRATEGIES AND MEASURES FOR EFFECTIVE PUBLIC PARTICIPATION IN DEVELOPMENT PLANNING AND MANAGEMENT}

\section{A... Intraduction}

42. From the issues raised in the preceding sections of this repprt, it is evident that, like development planning and management, public participation is a multi-dimensional process which is at the centre, of, economic; recovery: and development because it encompasses the $;$ human dimensions of development. Inadequate public participation in deyelppment processes has adversely affected the pace of progress and, highten tensions especially amongst those, who have no access to the wherewithal for food and other basic human needs for bare survival.. This, then, is the backgroupd against which, strategies and measures for effective publice:participation in development. planning and management are being suggested. : It has already been : indicated that Africa is a mosaic of , heterogeneous nations: which share, certain common characteristiç iof underdevelopment. Consequently, the strategies and measures, proposed, in this section are therefore broad. In effect, they are not intended to compromise the uniqueness of each country nor are they a critique of efforts currently underway to operationalize public participation in various African lcountries. As broad-based, strategies; they present: options which each country could consider against the background of it: it. chosen; path to social and economic development for popular public: participation. strategies and measures proposed are at three levels:

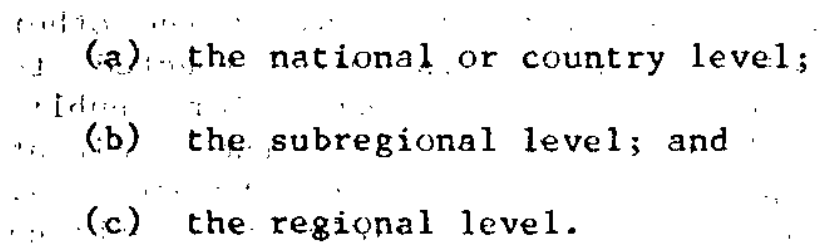

Needless to reiterate that strategies and measures at the above. three levels are interrelated and should therefore be treated as such. : The aim is to achieve sustained national sccio-economic transformation, recovery and development.

\section{B. National Strategies and Measures}

\section{(i) Political Mobilization}

43. Political mobilization is considered as the sin qua non of public participation in development management. Political 
mobilization has several objectives $19 /$ including (a) the entrenchment of political or social domination of one group by another group of people in the country: (b) the economic exploitation of the powerless; and (c) the emanipation of every person from both social domination, psychological and economic exploitation. Thus for political mobilization to have a positive impact on social-and economic development on a sustained basis it must be emancipatory in all aspects. Emancipatory political mobilization seeks, to (i), redress skewed of unfair distribution of power and wealth; (ii) create or expand the avenues for popular particlpation and healthy. initiatives in production for national development; (iii) promote the peoples', especially peasants', self-confldence in their own abilities and capabilities; (iv) encourage the spirit of national cohesion and discourage colonially induced parochialism which subverts development plans and undermines effective economic management; $\left(v^{\prime}\right)^{\prime}$ inculcate development-based work ethics which should flow from the demonstrated exemplary conduct of leaders from all walks of life in the society; and (vi) pursue electoral processes which would convince, at least, the powerless majority that they have every democratic opportunity to choose and to change leaders who are or are not the genuine accredited representatives of the public.

\section{(ii) Enabling Environment}

44. Creation of an enabling environment as a strategy of development entails so many issues. At the national level, the actors in the development paradigm include the bureaucracy or government administration, the ruling political party, the business community, the peasants and individuals who do not fall into any of the other categories indicated here. All these actors are expected to participate and create the enabling environment for public participation in development. However, because of the dominant and central role of the ruling political party and the bureaucracy, the government should play the leading role in building the enabling environment for development. Creation of an enabling environment should entail respect for the rule of law and order irrespective of an individuals status in society; respect for consistency and continuity in the constitutional rights of all citizens and alliens in a country; and the provision of the infrastructure for the creative

$19 /$ S.S. Mushi, "Political Mobilization for Rural Development: Some Lessons for an independent Namibia" (mimeograph) Discussion Paper presented at ILO (EmP/RU \& SATEP), SWAPO of Namibia and UN Institute for Namibia Workshop on Rural Development: Options for Namibia Cooperative College, Lusaka, Zambia, 2-15 October 1983. 
initiatives of individuals. The police, gendarmes and the armed forces should be made the true friends of the members of the public. The political, economic and psychological dimensions of the environment for development neer to be carefully analysed and harnessed in the national interest.

\section{(iii) Establishing Institutions for Popular Participation}

45. The institutional basis of public participation is equally important. All the countries in Africa have accepted the decentraliation of povernment administration and machinery as the surest way to bring about popular participatory democraey in development. . The point is that African countries are not larking in the institutional framework for development planning and economic mansgement. Village development comittees, district/divisional development committees, provincial/regional development comittees; and development planning directorate/national planning agency which have been established since independence in almost every country to implement government policy on decentralization should be used to induce public participation. The lesson is that institutions per se do, not guarantce public participation. The functioning of inseltutions. is more important. A management audit and ituational analysis of the current institutional framerork for development would provide pertinent data for institutional reforms in the context of Africa's economic recovery and sustainable development.

\section{(Iv) The Armed Forces participation in Civilian Production}

46. Armed forces participation in civilian production especially In ruxal development and agriculture could be considered as a strategy of public participation in development. Some governments in Africa have coopted members of the military and the police force into the ruling party, diplomatic missions and parliament. This could be considered as a scep in the right direction. Other countries have creeted a military-based national service wilch is self-suffictent in food production. It is, therefore, suggeste here that the huge amount of equipment (other than bomis and bullets) used by the army be used in development programmes which could hoost public participation in development. For example, the army corps of englneers could work on rural roads, dams and other clvil works. The army could help peasants during the planting and harvesting seasons and spearhead other community development projects alongalde the comounities in which they live.

\section{(v) Esucation}

47. Educatión for public participation in development is most essential. This should begin at the family level. It is important for everyone in society to understand and anpreciate the different strands of public participerion in devolopment. The concept carries 
with it the duty or obligation to contribute to the costs as well as the right to share in the benefits of the cultural and riateriat progress of the society in which one lives. The urban population should be educated to participate in development programes involving labour-in-kind.

(vi) Employees-Employers Partnership in Enterprises l.anagement

4i. Public participation at the enterprise level in every country should be propagated as a step in the right direction. Vorkers contribute their labour and should have the right to share in cost dectsion-making and also the surpluses generated. With hindsight, employers have historically been reluctant to share decision-making and excess profits with workers. In some cases employers have often argued that workers are not knowledgeable in the intricacies of corporate management to be able to farticipate in decision-naking. The paradox is that it is these same employers, who point accusing fingers at the government for stifling business initiatives by not allowing them to participate in national investment deciston-making. In some cases work councils have been established and trade unions have" become an accepted component of industrial relations in the majority of African countries. The indigenisation strategy underin the 1374 Higerian Enterprises Promotion decree sought to invalva ligerians in joint ventures with alliens, with the aim of achieving national decolonisation of the economy. 20/ The requirements for indigenisation of the economy are rigorous. The citizens must maintain the same or improve on, the standard of the performance of alliend bearing in mindmete fact that the rioks of fatlure are too high. Hot only is investros' money involved but also the jobs. of empioyees and thr welfare of their fanilies, the interestes, of the consuning public and the national goals of socio-econonic i. development. Thus, at the individual level, each person in the country must learn, in the paraphase of the late U.S. President. John F. Kennedy, to ask not what the country has done for him/herbut what he/stie has done to further the development interests of his/hè nation.

20/ See Keynote Address deliveres $\mathrm{y}$ Chief 3.0. Adebo on March 7-9 1974 at a Conference on "Pianagement Fevelopment:, The Challenge. of Iridigenisation" "University: of I jadan, Higefia,

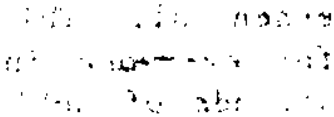




\section{(vii) The Use of Gelf-helo Groups}

49. Self-help groups or non-governmental organisations (IGGs) should be used to progagate the essence of public participation in all African countries. "COs in African countries include thrift societies in urban and rural areas, mutual self-help labour groups of men and women in rural areas, village development associations whose membership may extend beyond the viliage to include all the village descendants who may be employed outside the village, production and consumer cooperative societies which have been created at the grassroots by the people themselves and not imposed by the government. In recent years there has been a proliferation of liGos from foreign countries in Africa. They seem to have inspired the revival of the NGCs culture in Africa. lGOs strife to be independent of the state bureaucracy in decision-making and endeavour to identify more with.the underdog and grassroots development. 21/ African countries should regard IYGOs as very important partners in national development. African countries should take IIGOs as development partners and should holdridialogue with BGO representatives. The didlogue between governments and $\mathrm{bGCS}$ could contribute inmensely to the inducement of spontaneous public, especially grassroots participation in the economic transformation process of African countries: Solidarity between indigenous and foreign vGos should be encouraged. It is essential for local HGCs to aluays bear,in mind theiricountry-specific rootsif and the genuine development and welfare aspirations of the nation and not to give cause to the political leadership to suspect. the good relations and solidarity which may be estrablished between local and foreign IICCs. IGGs could be a major force in the inducement of spontaneous public participation in Africa's economic recovery and sustainable development.

\section{Subregional Strategies and Measures}

50. The rationale for subregional strategies and measures of puhlic participation is to provide prelude to regional or continental

21/ See Akpalo Kovassivi, "The roles and hesponsibilities of liongovernatental organizations ( $I C \mathrm{Cs}$ ) and Crassroots Communities" E/ECA/ICPP/gO/2.2. The characteristics of lloos articulated in this paper. do not reflect the reality of richs in action for instance financial independence of European l.r.s is untenable, and, paul rlangoola, "Promoting Indigenous loss as Instruments of Popular Participation" paper prepared in the International conference on Popular Participation in the fecoveiy and Developitent process in Africa; $12+26 \mathrm{Feb}$. 1990 , Arusha, Tanzania. 
approach to development because many Africar countries are at present too small to benefit from the economies of scale so essential for the establishment and management of basic industries for the production of agricultural, industrial and infrastructúral inputs. Public participation at the subregional level is vital for development through subregional economic cooperation.

51. Bearing in mind the unique problems of group of countries in Africa's subregions, intergovernmental authorities could be established for public participation in joint programes. For example, in drought prone subregions such as the Sahel, Intergovernmental Authority on Drought and Development could be established and people in the respective countries encouraged to participate in joint tree-planning programmes or to. jointly tackle environmental problems of desertification. In the case of island nations, participatory programmes of trade and transport linls with the mainland nations could lead to mutual socio-economic development. Strengthening of existing subregional economic organisations in Africa would foster. the consideration of public participation at the national and subregional levels.

\section{Regional Strategies and Keasures}

52. At the regional level, conferences, seminars and workshops could be organised from time to time to promote dialogue and the cross-fertilization of ideas on how best to go about sustaining public participation in community and national development programes.

E. Constraints on Sustained Public Participation in Development Planning and Management

53. Given that leaders from a!l wa!ks of life in Africa are committed to the ideals of popular public participation in overcoming the challenges of the current social and economic crises, what then are the constraining factors? The constraints on the operationalization of public participation are external and internal or domestic.

\section{(i) Constraints it the lational Leve1}

54. Political factors would seem to be the most enduring factors at the national level which could either inhibit or inspire genuine pulic participation in national development. Fxigencies of political survival, irrespective of ideological underpinnings, tend to take precedence over the participatory requirements of economic realities.

55. The diminished confidence of the public in the integrity of the state bureaucracy, the attitude of public servants to the general public and particularly to the peasant taxpayers, the dwindling productivity of the demoralised workers, and the repressive apparatus 
of the armed forces all culminate in the stifling of individual and collective initiatives which would have been harnessed for national development. The rampant collapse of the banking system in some African countries in recent years has further destroyed peoples confidence and thus impede the mobiiisation of savings for development.

56. The demonstration effect of the conspicuous consumption of a few vis-a-vis the majority in each society has the effect of dampening the enthusiasmi of the majority to sacrifice their rime and meagre financial resources for the common good. The less privileged find it difficult to differentiate between luxuries genuinely acquired and luxuries acquirer through corruption and/or the embezzlement of public funds.

57. The legal framework and legal practices could also become obstacles to public participation. Arbitrariness of arrests stifles public participation. In some countries colonial laws which prohibited Africans from planting food crops which would compete for labour with the colonialist plantation requirements or make the African selfosufficient in food production are still on the statute books and are implemented by the state police apparatus. This is damaging not only to development but also discourages initiative and public participation.

58. The attitude of men to women in Africa is also a source of problems. Even though worien are the major producers of food in Africa, their contribution to development has not been given the credit it deserves. Ahove ali, women are not accorded key roles in the decision-naking processes of social and economic development. The low ranking accorded to the status of women in development planning and managenent has had detrimental effects on national development.

59. The reluctance to come to terms with the realism of international commodity trade has distorted the focus of public participation in agriculture. For example, fluctuations in the prices of cocoa, coffee, rubber, tea, etc. is not a new phenomenon. However, instead of diversification into crops for domestic consumption or building local resource basis for agromindustries to consune the erstwhile exports, most African countries have been lagging behind in changing the production mix of their economies. Price booms for raw commodity exports should be regarded as a thing of the past.

60. At the international level, approach to negotiations for the inflow of foreign resources tends to ignore or underplay the fact that aid donors have the interests of their own taxpayers to protect. In addition the taxpayers in other countries have become weary of the mismanagement of aid which is allegedly rampant in some African countries.

61. The foregoing constraints are compounded by natural forces such as drought, locusts, mosquitoes, snakes, crocodiles, harsh 
ECA/PYSD/PAMl $/ 90 / 4(1.2)(\mathrm{i})(\mathrm{d})$

Page 32

climatic environments and home grown internicine wars of attrition. These latter not only result in the vaste of local and external resources that would have been used for development but also cripple economic activities as well as create armies of disabled youths. Whereas it is easier to obtain the weapons of war, it is enormously difficult to mobilize the resources that are required to take care of disabled and destitute populations so rendered by the attrocities of domestic military conflicts.

62. The perpetuation of the pre-independence promises of free social services (education, health, subsidized food and transport services, etc.) has tended to increase the dependency syndrome of the population on the government. These promises were pertinent given the magnitude of deprivation of the people of social services at independence. nowever, because no time limit was placed on the duration of free social services, in time, the majority of the population has become used to these free services given by the government and would resist any attempt to levy expenses on services that used to be provided free of charge.

63. The constraints enumerated here are not exhaustive but could be considered as adequately indicative of sone impediments to public participation in Africa's economic recovery and development process, especially the proress of development planning and managerent. 


\section{SECTIOA IV}

\section{CONCLUSIONS AND RECOMBEHOATIOINS} FOR POLICY ACTION

\section{IV.1 Summery Conclusions}

64. The emerging consensus in Africa is that public participation is central to development planning and management. The planning process is not the. prerogative of technocrats but should involve the accive participation of the people in the conception, formulation, implementation and management of all the forces of development.

65. A cormon understanding, and asreement on the usage of expressions such as PiDLic and POPJLAì participation are important not only for the sake of the clarity vhich development planning practice requires but also to forestall any detraction frorn tine real issues of the inherent relationstip between human beings and the process of development and management. The amexsing conclusion, therefore, is that the analysis of both planing and econonic managenent as well as public participation in Africa should now be based on the political, social ard the economic evelopment realities of the 1980 s ano beyond.

66. Public participation galvanizes the masses of the people against colonial rule. Its effectiveness has been demonstrated over and over again in the decolonisation and the independence of most African countries. Ilowever, the pre-independence public participation paradigm is now inadeguate tc meet the aunting challenges of internal and excernal pressures; the increasing, romplexity of the international economic system and relations; and the increasing sophistication of societal demands on government arministrations in contemporary Africa.

67. For public participalion to be poputar"in the sense of general acceptability by the vast majority of the people in each country, it must be seen to the genuinely spontaneous and not manipulated, orchestrated or suntly coerced. The requirements of spontaneous public participation must be clearly understood. In this connection, public participation is not something that governments must do for people but rather what people must do for therselves in their own interest and that of tha country.

68. Fublic participation is thus the aggregation of participation in household affairs, in individual corporate managements, partnerships, sole propriecorships, charitable organisations, nongovernmental organisations (ivos) and in government administration which has overall responsibility for national economic planning and management. All the actors indicated herein should, therefore, share responsibility for the creation of the rnabling environment 
ECA/PISD/PAL $/ 90 / 4(\lambda .2)(i)(d)$

Page 34

which is the sin qua non of public porticipation in development planning and management activities. The creation of an enabling environment should begin at the household level. Resistance to workers' participation in private and public sector firms is, for instance, not condusive to the promotion of a enabling environment for participation in planning at the national level.

69. The plannirg and the managenent of development activities' should move away from arachronistic theories which were based on the objective realities of Europe. In this regard the contours of development issues enshrined in the African Alternative Framework to Structural Adjustment Programes for Socio-Econonic Recovery and Transformation (AAF-SAP) could be elaborated to good advantage. Tlus, public participation could be posited in the context of the expectations of the AAN-SAP.

70. Another emerging conclusion from this report is that the monitoring of the mobilisation of financinl resources should be one of the criteria for the evaluation of the ingnitude of public participation in national dovelopne." planning and management. It would be unrealistic to argue that zuantification is not of essence in the monitoring of public participation. Wable 1.1 of this report shows the total $(\$ 20,104.5 \mathrm{million})$ financial resources required for Africa's economic recovery proprane in 1986-1990. Out of this aggregate outlay $\hat{\$} 02,4: 7.4$ million $(64.4 \%)$ are expected from the population of Africa and $45,617.5 .35 \%$ fror the taxpayers of other countries. It could be argued that the extent to which these sums of money are realised in practice would somenow reflect the extent to ihich local anc foreign taxpayers are prepared to contribute to and hence participate in the national planning and recovery programes of individual countries. Thus:" innovative perspectives on the dimensions and reguirements of public participation are essential for a clearer understanding of the sacrifices that are expected of every person in the sociely.

71. On the issue of the centrality of government in the planning and managersac of development based on popular public participation, this report cannot but agree more with the Lar-es-Salaam Declaration that alternative development in Africa should see the current crisis as a political crisis linked to a basic contradiction between state pover and people's pover. resolution of this contradiction through urgent democratisation vith effective popular participation at all levels in decision-making, resource mobilisation and allocation would strengthen and enhance the basic role of the state in development through effective planning. This demands patriotic leadership and accountability at all levels of society to sustain meaningful growth, and development. The accredited representatives of the people must be accountable to the people."

72. It could be argued from chese conciusions that the problem is not with what to do to promote public participation but with 
how to do it. The Daras-Salaam Declaration notes, in the same vein, that the most basic problem with alternative development strategies, ircludins puslic participationg in Africa is their implementation, To overcome this fundamental problem, it has been suggested that development, documents in Africa must he based on socio-economic realities and must become political documents that should be videly disseminated and debated. In this way, the popular forces of workers, peasants, women, students, progressive intellertuals, patriatic professionals and politicians will be mobilized to participate spontaneously in the development efforts of the nation.

\section{IV.2 Recommendations for Policy Action}

73. Decisive policy medeurcs and action are required in all fufrican countries to overcome impediments to peoples participation in development planning and management. The recommendations made here will assist to contribute to the efforts which African countries are making to ensure that public participation becomes a way of life in all development activities. In this regard, the recently concluded International conference on Popular Participation in the Recovery and Development Process in Africa and the resulting. African Charter for Popular Earticipation in Development and Transformation (Arusha 1950), are of paramount importance. The recommendations made in the ensuing paragraphs are derived from the premise that full and effective participation by the masses together with the governinents in development planning and management will speed up the attainrent of sustainable socio-economic development in Africa.

(i) Tie national tevelopment plans of African countries must contain explicit policy measures on public participation. This entails the adoption of developmert planning strategies which coincide with the intrinsic interests and the aspirations of the people. These strategies should incorporate, rather than alienate, the economic, social, cuicural and environmencal realities of each country. The determination of these realities should be the prerogative of the people themselves.

(ii) The creation of an enabling environment must not be regarded as the responsibility of the government alone but rather as the obligations of households, firms, iGOs and all other actors in partnership with the government in the development and management process. In this rogard each country should establish an Extension Service for Public rarticination (ESPP) in development planning. The ESPP would, inter alia, create awareness through the education of the masses on the platitudes of people-based development planning, democratisation of the development process, and the sacrifices people must be prepared to make to ensure the success of development plans which they themselves have formulated. Thus the ESPP must begin at the family level as the foundation of people-based development and extend to schools, the work place, in all organisations and all walks of life in society. 
(iii) iven that the quality of development jepends on the cliaracter of the political system, African countries hould re-assess

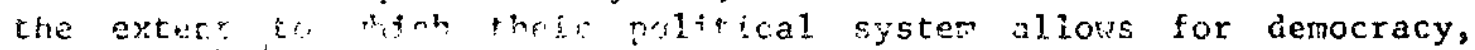
Ereedom of ofinions, tolerance to differences, and full participation in hevelopment by all sections of the population. In this regard, political systems in Africa should be raken as instruments of promotirg public participation in development planning and managenent.

(iv) At the international level, there is need for African governents tc evaluate the role and performance of their diplomatic missions in the promotion of external public participation in each country's development planning and inanagement. Embassies must be equipred with the capacity and capabilities to enharce national efforts to seek external resources gap support from bilateral and multilateral donors and transnational corpoxations. 